\title{
COMMUNICATING BOGOR CITY AS CITY HERITAGE THROUGH SPATIAL CITY
}

\author{
Mariana R.A Siregar ${ }^{a)}$, Diana Amaliasari ${ }^{a)}$

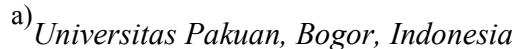 \\ Corresponding Author: ristasiregar@yahoo.com
}

Article history: received 09 January 2019; revised 27 January 2019; accepted 01 February 2019

\begin{abstract}
City branding is an effort to build the economy of a city,country or province. Study about city branding is part of city planning that aims to build differentiation and strengthen the city brand. Bogor City as one of the cities that have the potential of its culture but still have not determined its capital brand. This research aims to find out how Bogor implement the primary communications strategy. The strategies include landscape, infrastructure, organizational structure, administration, and also culture behavior approach. Qualitataive method used to determine the most influential approach to city branding. Information gained through in-depth interviews to several stakeholders and files. This study find several outputs such as: The strategy of landscape approach and infrastructure approach mainly supported the establishment of Bogor as heritage city. Meanwhile Organization structure and administration approach as well as the culture behavior already existed, but the implementstion still not optimal and not clearly visible.
\end{abstract}

Keywords: City Branding, Bogor, Landscape.

\section{INTRODUCTION}

City branding is part of city planning that aimed to build differentiation and strengthens the city image. In Indonesia, city branding has been widely proclaimed by several large cities, such as Jakarta with the slogan "Enjoy Jakarta," Surabaya with Sparkling Surabaya, Jogja Never Ending Asia, The Beauty of Asia as and Solo with The Spirit of Java. However, referring to some of the research results, the groundbreaking city branding in several cities in Indonesia is not well - assessed, due to factors such as there is coordination between system and govenrment rules.

Bogor as one of cities that have various potential sources such as cultural heritage, culinary, and panoramic tourism sites still not define its brand. In November 2016, at the office hall, Bima Arya, as mayor of Bogor, held a meeting with Chrisna Duta Mandiri (CDM) as one of city branding consutant to build Brand of Bogor. It is direcly stated that Bima Arya did not have any plan to build Bogor Brand because his priority is on the infrastructure. At that opportunity Bima stated that Bogor did not have any financial support to promote City Branding because Bogor still focusing on improving the City landscape strategy and physical infrastructure. Bima also mentioned that promotion budget was not sufficient to do branding promotion. Bogor government is now focus in improving the potential sites in Bogor, especially related to historical sites and its demography.

Referring to concept introduced by Kavaratzis [1], in order to determine the city's brand and its management in relation to its literature review of the city and its brand. City branding can improve local economic and also identity to its society. Through city branding, a city can strengthen the resource and increasing investment and tourism. He explained that in order to improve city branding there are three type of communication, i.g: primary, secondary, and tertier communication. Despite of conducting promotion as secondary communication that is costly, the government of Bogor still try to improve the image of the city through infrastructure quality improvement or categorized as primary communication.

Based on previous explanation, related to primary communication in term of city branding improvement, the main question of this study is "How Government of Bogor communicate Bogor as Heritage City through Spatial Planning Policy?.

From the problem identification that has been mentioned, the objective of this research is explaning the Sptial Planning Policy as Bogor government communication strategy to build Heritage City Branding.

\section{City Branding Communication Strategy}

One of difficulties in improving brand of a city is that there are large numbers and spread stakeholders to be achieved. City brand is the selection and use of means to communicate the image to be built in public. The public has a certain image of a city even though they have never visited but have never exposed to promotional communication programs to the city. Referring to the theoretical framework of Mihalis Kavaratzis [1], image of the following city will be the basis of analysis of branding strategy of city branding Bogor City. 


\section{Primary Communication Strategy}

Landscape strategy' refers to areas of action and decisions relevant to urban design, architecture, green spaces and common spaces in the city. The increasingly popular use of public art is also included in this category, along with inheritance planning. This component is similar to the product component of traditional 4P marketing and has been suggested in urban marketing theory as a design (Kotler [2]) and as the first part of the 'spatial functional measurement' of Ashworth and Voogd in Kavaratzis [1]. The urban marketing as practiced so far are often identified with urban design and marking of places (Griffiths [4]) or the amount of massive physical rebuilding and public art (Hubbard and Hall [5]) in Kavaratzis [1] .

'Infrastructure projects' refers to projects that are developed to create, enhance, or characterize the various types of infrastructure needed in a city. On the one hand, these framework elements must be done by improving the city's accessibility to a wide range of society, whether the accessibility of the highway to the inhabitants, the accessibility of the main monuments to the visitors or the presence of a large airport. On the other hand it refers to the existence and adequacy of various facilities such as cultural centers, conference facilities, etc. The infrastructure project as a component of the city brand has the same meaning as the infrastructure (the place as the fixed environment) as suggested by Kotler [2] and is the second part of the Spatial functional measurements of Ashworth and Voogd [3]. The most important elements of this category are the community development network and citizen participation in decision-making, together with the establishment of public-private partnerships. The marketing and branding organizations themselves include in this category.

\section{Secondary Communication Strategy}

Secondarycommunication strategy is an intended formal communication that commonly happened through marketing promotion such as indoor advertaising and out door advertaising, public relation, graphic design and logos. Secondary communication is meant by the promotion (Ashworth and Voogd [3]) and by advertising and promotion Hubbard and Hall [5] and Griffiths [4]; it is part of what Balmer [6] describes as a component of corporate identity communication in Kavaratzis [1]. This is what is regularly confused in the city's marketing practices with all efforts to shape the brand (branding), so it is useful to emphasize once again that secondary communication must be in complete harmony with other components in shaping the image of a city and also aligned with the city's realities encountered by various city audiences.

\section{Tertiary Communication Strategy.}

Tertiary communication strategy is a secondary communication strategy that has to be strengthend and supported by mass media or being re- production by other media. The important thing about tertiary communication is how far societ is acknowledged with the promotion and eager to spread the message widely.

\section{RESEARCH METHODS}

This research is designed as a qualitative research that combines descriptive research with explanatory research and explanatory research. The research method used case studies, which is used in real-life exploration research, contemporary limited systems (cases) or various limited systems (various cases) through detailed and in-depth data collection involving multiple sources of information or multiple information sources (observations, interviews, documents, and various reports), and report the description (Creswell [7]). Singarimbun and Effendi [8] explained that descriptive research is a study that provides a more in-depth picture of certain social phenomena or specific aspects of life in a particular society studied

Bogor was chosen as the study location due to several reasons such as: (1) Smart City that has three pillars. These three pillars can be seen as an effort to build city brand. (2) Bogor is included to Jaringan Kota Pustaka Indonesia (Indonesia Heritage City Network). This research was conducted for 8 months since August 2017 until March 2018. There are 5 steps in this research: (1) Research Proposal, (2) Desk Study, (3) Field Research, (4) Research Data Compilation, (5) Final Report.

This research identifies several sources of information related to the three concepts of Bogor City identity, namely Bogor as Heritage City, Bogor as Green City and Bogor as Smart City. Based on the results in pre- research stage, the stakeholders of city branding strategy of Bogor City are the Head of Publications and Public Relations Sub-Section and Bogor City Government Protocol, Head of EGovernment /Diskominfostandi, Head of Spatial and Environment Division/ BAPPEDA, and Head Department of Tourism and Culture/Disparbud.

There are several data collection method used in this research, such as indepth interview, literature review, and observation. Indepth interview is used to obtain the information related to the Bogor Government strategy in building city branding to their internal public and (2) obtain information about their strategy to external public. (3) Identify the physical infrastructure as part Bogor Government primary communication strategy to improve the city brand. Literature review used to analyse documents and collect qualitative data from mass media such as from magazine, newspaper, journal etc. 
Data Triangulation is exploring the truth of certain information through various methods and sources of data acquisition. This research has a lot of data validation using data source triangulation with Public Relation Officer of City of Bogor and head of Organization of related Regional Device, library study in form of official document, including annual report, RKPD, RPJMD, Tourism Data, DIKLPH's main report, Heritage City Socialization, Smart City Strategy Analysis Book, archives, official records, official website of Bogor City government along with official website of each OPD, and other related articles.

\section{RESULTS AND DISCUSSION}

\section{Spatial Planning Policy As Primary Communication Strategy To Present Bogor As Heritage City}

Bogor as one of the cities that have a lot of potential naturel tourism site, culture, and culinary, until the year 2018 still not determine city brand. Bima Arya, Bogor Mayor period 2015-2019 was currently focused on improving to infrastructure. Bima Arya, when Bogor Government conducted meeting with PT. Chrisna Duta Mandiri (CDM), one of the strategic planner consultants who offer help form the city brand of Bogor. The unavailability of the budget for the city branding program, he explained that the budget for promotion is not sufficient. Bogor is know focused on infrastructure. This consideration is also supported by the inclusion of Bogor city as one of the areas that entered into the Indonesia Heritage City Network (Jaringan Kota Pusaka Indonesia) established in 2008 which is an organization among the city government and or regency governments that have a diversity of nature and cultural heritage (tangible and intangible) with the main objective is to preserve the heritage of nature and cultural heritage as the basic capital of future development.

The implementation of Bogor City as heritage city is implemented in spatial planning of Bogor City, which is "Implementing Sustainable, Productive, Convience City through Environmental Based Spatial Planning". This spatial planning is translated into policy of cultural heritage preservation in RPJMD and RPJP Bogor city into four sectors, economic, culture, education and tourism sector. There are some communication strategies according to Kavaratzis [1] as an effort to communicate Bogor City as Heritage City in various sectors through landscape strategy, infrastructure project, organization and administration, and behavior in strengthening the identity of Bogor City as Heritage City.

\section{Landscape Strategy}

Spatial planning strategy by revitalizing several cultural heritage areas and maintaining the characteristics of buildings, cultural heritage areas, consisting of several categories, such as: Government buildings revitalization such as Bogor Palace and Batutulis, Kodim and Korem Headquarters, National Land Agency Building, RRI Building, Museum Zoology and Monument and Map Museum, Raden Saleh Tombs, Research Institute of Bio Technology Plantation of the Republic of Indonesia, and Indonesia Post Office. Worship buildings revitalization, namely Katherdal Church, Zebaoth Church, Regina Pacis Chapel, Empang Mosque, Dhanagun Pagoda / Hok Tek Bio. School building revitalization, SMA YZA 2 and Junior - senior high school (SMA - SMP 1). Public facilities revitalization, Railway Station, Salak Hospital, Orphanage "Bina Harapan", Hotel Salak on J1. Ir. H. Juanda. Historic Sites Revitalization, Batu Tulis.

\section{Infrastructure Project}

Reducing development pressure in the city, especially in the core heritage area, developing the conservation scheme of heritage and its assets are some aspects that will continue to be done by the city government as stated in the Document of Regulation Plan of Bogor Heritage Area in 2014. Although these efforts have not yet been supported by public transportation planning in minimizing congestion in heritage centers. The One Direction System (SSA) still cannot reduce the congestion significantly in some heritage areas.

\section{Administrative and Organization Structure}

Incorporating Sundanese language curriculum as a local content is a part of organization structure and administrative. Another involvement in educational institutions is to promote the arts and culture level competition from kindergarten to high school. Stakeholders' support in effort to shape the image in internal public is by intensifying investor or entrepreneurs engaged in hotel accommodation services, by which serving unique food and make this city as one of the culinary tourism destination, especially in cultural heritage. The most important element of this category is establishing community development network and citizen participation (as an internal public as well as an external public). This kind of internal public relations can help the city government in shaping the desired-image (Jefkins, [9]). This can speed up investors and potential investors to make decisions.

\section{Behaviour}

Head of Tourisme and Culture Department said that the internalization of Heritage City, Green City, Smart City is carried out by the Department of Tourism and Culture to every employee who is in hotels, cafes, restaurants, places of tourism with several implemetation. One of it is implementing Tourism Movement Group (KOMPEPAR). KOMPEPAR is one 
of communities who responsible in assisting the promotion Bogor City. This makes the promotion of Bogor City tourism more effective with the existence of several communities that helps.

\section{City Spatial Planning As City Branding Communication Strategy}

Referring to the Kavaratzis theoretical framework [1], in shaping the city branding he stated that there are several strategies can be applied such as landscape strategies, infrastructure projects, organizational and administrative structures and behavior. These four things are able to shape and build city image. Bogor major also stated that government of Bogor still maximizing the infrastructure before entering the second phase of communication strategy. This research finds that landscape, infrastructure project, administrative, organization structure and behavior can improve city branding.

\section{Economic Sector}

Cultural heritage revitalization can strengthen Bogor city branding as Heritage City. The existence of Bogor Palace, Batu Tulis Palace, and Bogor Botanical Garden are also improving the image of Heritage City. Through cultural heritage revitalization Bogor can increase the number of local and foreign tourist visits. Revitalization of pedestrian and infrastructure is also part of optimizing the tourist destination. One Way System (SSA) nearby center of cultural heritage can be utilized by Bogor Government to improve the city of runner image and green city. Revitalization is also attempted in order to optimize these tourist destinations with the arrangement of pedestrian/pedestrian infrastructure. Through the change of pedestrian path and one-way system path around the cultural preserve utilized the government of Bogor City by making the city as a city run. This means that the use of pedestrianfriendly infrastructure has added the image of the city of Bogor as a comfortable, green, and cool city to run

\section{Cultural Sector}

The Revitalization of cultural heritage areas has also made internal and external public acknowledge that Bogor City has historical value. This can be seen with the development of Chinatown area on the road Suryakencana by building Lawang Suryakancana. So far, this area is known with its slum. Whereas in this area there is also the main entrance of Bogor Botanical Gardens, and Zoological Museum frequented accessed by tourists. This area has already been well - organized by government of Bogor by managing street vendors and implementing one- way system. Suryakencana is also a place where Bogor Street Festival Cap Go Meh 2018 taken place. Now Suryakencana is known as one of the iconic places in Bogor City. This is impact the local revenue (PAD) because this activity became national and international coverage.

\section{Education Sector}

Education policy is contributes to improve the image of Bogor by (1) integrating local language into academic curriculum from elementary school untul senior high school (2) conduction competition in cultural and arts from kindergarden to senior high school. By introduction culture since primary school it is expected it will increase student awareness towards history and culture. So that, in the future, this student will become agent who will promote culture to their friend.

\section{Tourisme Sector}

Tourism Movement Group (KOMPEPAR) is important in improving Bogor Image. KOMPEPAR is one of communities who responsible in assisting $\backslash$ depertment of tourisme and cultura to promote Bogor City and preserving cultural heritage in Bogor City. This makes the promotion of Bogor City tourism more effective with the existence of several communities.

\section{CONCLUSION}

Currently the logo and slogan still has not been published. Government of Bogor is still using city spatial planning as primary communication strategy. This strategy is focusing on infrastructure revitalization and spatial planning as their main programs. The improvement of city branding is also supported by landscape, infrastructure, organization structure, administration, and internal and external behavior strategy. Landscape strategy is the most significant strategy in constructing Bogor as Heritage City. Optimizing the tourism movement group also the positioning of Bogor city as heritage city.

\section{REFERENCES}

[1] Kavaratzis, M. 2005 From City Marketing To City Branding: Towards A Theoretical Framework For Developing City Brands. Henry Stewart Publications Vol. 1, 1, 58-73

[2] Kotler, Armstrong. 1999. Prinsip- Prinsip Pemasaran. Jakarta: Erlangga

[3] Ashworth, G. J. and Voogd, H. 1990. Selling the City: Marketing Approaches in Public Sector Urban Planning. Belhaven Press, London, UK.

[4] Griffiths, R. 1998. Making sameness: Place marketing and the new urban entrepreneurialism', in Oatley, N. (ed.) Cities Economic Competition and Urban Polic, Paul Chapman Publishing, London, UK

[5] Hubbard, P. dan Hall, T. 1998. The entrepreneurial city and the new urban politics', in Hall, T. and Hubbard, P. 'The Entrepreneurial City: Geographies of Politics, Regime and 
Representation', John Wiley \& Sons, Chichester, UK.

[6] Balmer, J.M.T. 2001. From the Pentagon: a new identity framework. Corporate Reputation Review, Vol. 4, No. 1, July: 11-22.

[7] Creswell, JW. 2012. Research Design, PendekatanKualitatif, Kuantitatif dan Mixed. Yogyakarta; Pustaka Pelajar

[8] Singarimbun, Masri dan Sofian Effendi, Metode Penelitian Survei, Jakarta: LP3ES, 2008.

[9] Jefkins, Frank. 1992. Public Relations. Edisi Keempat. Jakarta: Penerbit Erlangga 